\title{
Self-Employment of Latinos and White Non-Latinos in the Pacific Northwest, U.S.A.: Choice and Income
}

\author{
Abelardo Rodríguez ${ }^{1} \&$ Stephen Devadoss ${ }^{1}$ \\ ${ }^{1}$ Department of Agricultural Economics and Rural Sociology, University of Idaho Moscow, U.S.A. \\ Correspondence: Abelardo Rodríguez, Casa del Carmen, Calle 41 No. 481, 52 y 54, Mérida, Yucatán, 97000 \\ México. Tel: 52-999-923-3709. E-mail: rlabelardo@gmail.com
}

Received: September 1, 2013

Accepted: December 12, 2013 Online Published: February 25, 2014

doi:10.5539/jms.v4n1p1

URL: http://dx.doi.org/10.5539/jms.v4n1p1

\begin{abstract}
Using data from the American Community Survey 2005, 2006, and 2007 we quantify the socio-economic factors that determine the likelihood of being self-employed (SE) of Latinos and White non-Latinos in the Pacific North West, U.S., and how these factors affect their income. Only 5.5\% of Latinos are self-employed compared to 9.4\% of White non-Latinos and Latinos earn 30\% less than White non-Latinos. Non-linear decomposition results show that age and educational attainment explain $41 \%$ of the ethnic gap in the probability of being SE among the U.S. born. In contrast, gender, type of occupation, number of years in the United States, and good command of the English language explain $22 \%$ of the ethnic gap in the probability of being SE among immigrants. Linear decomposition of self-employment income (SEI) shows that age, marital status, and type of occupation explains $90 \%$ of the ethnic gap in SEI among the U.S. born; however, ethnic differences in SEI among immigrants are mixed. Thus, policies aimed to reduce the ethnic gap in SEI should take into account the skewed distribution of skills of Latinos, and the degree of transfer ability of immigrants' skills into the local environment. Reducing this gap poses the challenge of improving the skills of many self-employed Latino immigrants with limited choices or transferable experience.
\end{abstract}

Keywords: Hispanic, White non-Latino, self-employment, immigrants, occupations, education

\section{Introduction}

Hispanics or Latinos in the Pacific Northwest of the United States (PNW, including the states of Idaho, Oregon and Washington) are the largest and fastest growing minority and yet little is known about who is likely to choose to be self-employed or an entrepreneur and how they earn their income. This paper quantifies demographic and socioeconomic factors that determine Latino and White non-Latino self-employment and income in the PNW (Note 1). Rodríguez \& Devadoss (2014) discuss the factors determining the wage gap between Latinos and White non-Latinos. Self-employment is an alternative to those who want to make the transition away from wage labor because they perceive a prospect or had a major personal crisis such as the loss of a job, divorce or separation, among others. The former ones are described as opportunity-based entrepreneurs and the latter ones as necessity-based entrepreneurs (Acs, Desai, \& Hessels, 2008). For individuals and families in immigrant, ethnic, and minority groups who are marginalized by the traditional labor force, business ownership represents an important independent means to simultaneously earn a livelihood and achieve self-actualization (Puriyear et al., 2008). Independence may be a strong enough motivation for seeking self-employment and the American dream. Self-employment does not necessarily require a specific level of educational attainment though it is acknowledged that work experience is desirable and beneficial for businesses requiring special skills.

The Hispanic population in the PNW tripled from 380,000 in 1980 to 1,150,000 in 2007; ten percent of the 11.72 million individuals in the PNW are Latinos; $42 \%$ of the Latinos are foreign-born; and $82 \%$ of the Latinos are of Mexican descent (Pew Hispanic Center, 2008a \& 2008b). Data from the American Community Survey (ACS, 2008) show that only $5.5 \%$ of the Latinos in the PNW are self-employed compared to $9.4 \%$ of White non-Latinos. Research on Hispanic self-employment and business creation has shown that Hispanic males are substantially less likely to be business owners relative to Whites (Lofstrom \& Wang, 2007; Fairlie \& Woodruff, 2007). The self-employment difference is particularly large for Mexican-Hispanics, and the exit rate of those who own a business is twice that of White entrepreneurs. Because of their limited educational background and 
financial assets, Mexican Hispanics are more likely to enter into businesses with low-entry barriers (e.g., gardening/landscaping, construction, retail trade, or repair services). Robles \& Cordero-Guzmán (2007) find that the growing college-educated pool of Latino entrepreneurs is becoming more visible and requires researchers to recognize the bimodal nature of policy application for two distinct entrepreneurial stakeholders within the Latino business community. The emergence of Latino immigrant entrepreneurs and their earnings is particularly relevant for the PNW with a majority of immigrants being of Mexican descent.

The participation, age, and self-employment income statistics of White non-Latinos and Latinos during the period 2005-2007 are included in Table 1. There were 570,099 individuals between 18 and 64 years old in the PNW who reported self-employment income above zero, and 5.5\% of them were Latinos $(31,571 /(570,099))$ * 100. Self-employed Latinos, five to six years younger than White non-Latinos, are under-represented in the region where they comprise $10 \%$ of the population. The mean self-employment income of Latino U.S. born is $25 \%$ less than their White non-Latino counterparts and the mean self-employment income of Latino immigrants is $35 \%$ less than their White non-Latino immigrants.

Table 1. Age and self-employment income of White non-Latinos and Latinos by nativity in the Pacific Northwest, 2005-2007

\begin{tabular}{llllll}
\hline & & \multicolumn{3}{c}{ Self-employment } \\
& & Age & \multicolumn{3}{c}{ income (\$) } \\
\hline & No. Obs. & Mean & Std. dev. & Mean & Std. dev. \\
White non-Latino U.S. born & 516,797 & 44.8 & 11.5 & 31,114 & 51,395 \\
Latino U.S. born & 14,406 & 40.0 & 11.8 & 23,437 & 37,677 \\
White non-Latino immigrant & 21,731 & 44.0 & 11.3 & 36,503 & 53,122 \\
Latino immigrant & 17,165 & 38.1 & 10.2 & 23,615 & 37,038 \\
\hline
\end{tabular}

Source: 2005-2007American Community, weighted figures.

In order to quantify the socioeconomic factors that contribute to the choice of being a self-employed in the PNW and how these factors affect self-employment earnings we use two model specifications: one for the probability of being self-employed (binomial logit) and the other for self-employment income (semi-log) (Note 2). Model estimations are used to compute marginal effects in logit models and percentage effects in semi-log models. Each model is decomposed to ascertain the causes of observed differences between White non-Latinos and Latinos. The empirical results for the probability of being self-employed, the marginal contributions of different variables, and its non-linear decomposition to explain differences in the likelihood of being self-employed are discussed. This is followed by the empirical results of the semi-log models, the percentage effects of discrete variables, and decomposition to identify groups of variables that explain ethnic differences in self-employment income. In the last section, we present a summary and conclusions.

\section{Model Specifications and Procedures}

The model used to quantify the effects of socio-economic and demographic variables in determining the probability of being self-employed (SE) or an entrepreneur for White non-Latinos and Latinos in the PNW is

$$
\ln \left(\frac{\mathrm{P}\left(\mathrm{SE}_{\mathrm{ij}}\right)}{1-\mathrm{P}\left(\mathrm{SE}_{\mathrm{ij}}\right)}\right)=\beta_{\mathrm{ij}}^{\prime} \mathrm{X}_{\mathrm{ij}}+\alpha_{\mathrm{ij}}^{\prime} \mathrm{P}_{\mathrm{ij}}+\mathrm{e}_{\mathrm{ij}}
$$

where $\mathrm{SE}_{\mathrm{ij}}$ is equal to 1 if the individual of ethnic group $\mathrm{i}$ (White non-Latino or Latino) and nativity $\mathrm{j}$ (U.S. born or immigrant) reported positive self-employment income and 0 otherwise; $\mathrm{X}_{\mathrm{ij}}$ is a vector containing individual observable characteristics; $P_{i j}$ is a vector with population density and state characteristics; $\beta_{\mathrm{ij}}$ and $\propto_{\mathrm{ij}}$ are parameters to be estimated; $\mathrm{e}_{\mathrm{ij}}$ is the random error term; and the subscript $\mathrm{n}$ for the $\mathrm{n}^{\text {th }}$ observation is suppressed for clarity. See Table 2 for the variable names and definitions. Age, age squared, the proportion of metropolitan population, and years of residence in the United States for immigrants, are continuous variables. The rest of the variables are sets of dummy variables with a value of either 1 when an attribute applies to that observation or 0 when that attribute does not apply. Gender: female and male, with male being the base group; marital status: married, divorced, single, and widowed/separated, with the latter being the base group. Educational attainment is represented by four variables: lack of high school degree, high school graduate, some college or college graduate, and postgraduate or professional degree holder, with lack of high school degree being the base. Immigrants' 
good command of the English language is captured with a dummy variable. This is a self-assessed question in the ACS, which is subject to the individual's perception of her/his ability with the English language. There are 14 occupational groups: agriculture, forestry and fishery; construction; manufacturing; transportation and communications; wholesale trade; retail trade; FIRE; business services; professional services; personal services; entertainment and recreation; gardening and landscaping; repair; and other occupations_-professional services being the reference group. The state fixed effects are captured by dummy variables for Idaho, Oregon, and Washington, with the latter being the base.

Table 2. List of variables

\begin{tabular}{|c|c|c|}
\hline Variable group & Description & Variable name \\
\hline \multirow[t]{2}{*}{ Age } & Age & age \\
\hline & Age squared & agesq \\
\hline Gender & Gender & female \\
\hline \multirow[t]{3}{*}{ Marital status } & Married & married \\
\hline & Divorced & divorced \\
\hline & Single & single \\
\hline \multirow[t]{3}{*}{ School attainment } & High school graduate & hsgrad \\
\hline & High school to bachelor's degree & hstobs \\
\hline & Post graduate degree & pstgrad \\
\hline \multirow[t]{13}{*}{ Occupation } & Agriculture/forestry/fishery & agforfsh \\
\hline & Construction & cnstr \\
\hline & Manufacturing & $\operatorname{manf}$ \\
\hline & Transportation/communication & transcom \\
\hline & Wholesale & wholesale \\
\hline & Retail & retail \\
\hline & Finance, insurance, and real estate & FIRE \\
\hline & Business services & busserv \\
\hline & Personal services & persserv \\
\hline & Entertainment/recreation & entrec \\
\hline & Gardening and landscaping & gardland \\
\hline & Repair & repair \\
\hline & Other & other \\
\hline \multirow[t]{2}{*}{ State } & Idaho & idaho \\
\hline & Oregon & oregon \\
\hline Metropolitan population & Proportion of metropolitan population & mpop \\
\hline Years in U.S. & Number of years in the U.S. (immigrants) & yrsinus \\
\hline Command of English & Good command of the English language & engspkw \\
\hline
\end{tabular}

Data from the ACS 5\% Public Use Micro data Sample, for 2005, 2006 and 2007 is used, including individuals between 18 and 64 years of age. The proportion of metropolitan population (fractional value from 0 to 1 ) in a cluster of at least 100,000 people occupying part of a county, one county, or more than one county is done following the method provided by Hertz (2010). We use the non-linear decomposition method proposed by Fairlie (2005) to assess the differences in probabilities of being SE between Latinos and White non-Latinos due to their endowments or characteristics.

The model used to quantify the effect of socio-economic and demographic variables that determine self-employment income (SEI) of White non-Latinos and Latinos in the PNW is

$$
\ln \mathrm{SEI}_{\mathrm{ij}}=\gamma_{\mathrm{ij}} \mathrm{X}_{\mathrm{ij}}+\delta_{\mathrm{ij}} \mathrm{P}_{\mathrm{ij}}+\xi_{\mathrm{ij}}
$$

where $\operatorname{lnSEI} I_{i j}$ is the natural logarithm of annual self-employment income (2007 \$)of individuals of ethnic group $i$ and nativity $\mathrm{j} ; \mathrm{X}_{\mathrm{ij}}$ and $\mathrm{P}_{\mathrm{ij}}$ are vectors containing individual observable characteristics as above; the $\gamma_{\mathrm{ij}}$ and $\delta_{\mathrm{ij}}$ are parameters to be estimated and $\xi_{\mathrm{ij}}$ is the random error term.

The cases with zero or with negative self-employment income in the ACS are further excluded in the semi-log specification of SEI; Valdez (2009) also used only positive annual logged earnings. The percentage effects of the dummy variables are estimated following Kennedy (1981) and the linear decomposition method (Blinder, 1973; 
Oaxaca, 1973) is used to ascertain differences in SEI between White non-Latinos and Latinos as a function of observable characteristics.

\section{Empirical Results}

We first address the factors that contribute to the probability of SE. Then we elaborate on the factors that reduce or enhance SEI.

Table 3. Marginal effects and $\mathrm{Z}$ statistics of logit regressions for self-employed individuals by ethnicity and nativity in the Pacific Northwest, 2005-2007

\begin{tabular}{|c|c|c|c|c|c|c|c|c|}
\hline \multirow[b]{2}{*}{ Variable } & \multicolumn{2}{|c|}{ White non-Latino U.S. born } & \multicolumn{2}{|l|}{ Latino U.S. born } & \multicolumn{2}{|c|}{$\begin{array}{l}\text { White non-Latino } \\
\text { immigrant }\end{array}$} & \multicolumn{2}{|l|}{ Latino immigrant } \\
\hline & Marginal effect & $\mathrm{Z}$ & Marginal effect & $\mathrm{Z}$ & Marginal effect & $\mathrm{Z}$ & Marginal effect & $\mathrm{Z}$ \\
\hline agep & 0.010 & 24.6 & 0.006 & 3.9 & 0.008 & 3.7 & 0.008 & 3.8 \\
\hline agepsq & -0.00010 & -21.4 & -0.00006 & -3.1 & -0.00008 & -3.6 & -0.00009 & -3.6 \\
\hline female & -0.023 & -18.3 & -0.014 & -2.7 & -0.020 & -3.2 & -0.014 & -2.5 \\
\hline married & 0.014 & 4.4 & 0.019 & 2.1 & 0.019 & 1.3 & 0.004 & 0.4 \\
\hline divorced & 0.009 & 2.0 & 0.014 & 0.7 & 0.033 & 1.1 & 0.013 & 0.8 \\
\hline single & 0.007 & 1.6 & 0.020 & 0.9 & -0.023 & -1.4 & -0.008 & -0.8 \\
\hline hsgrad & 0.005 & 1.5 & 0.002 & 0.2 & -0.006 & -0.5 & -0.009 & -1.8 \\
\hline hstobsgra & 0.021 & 9.7 & 0.019 & 3.2 & -0.003 & -0.3 & -0.004 & -0.6 \\
\hline postgrad & 0.084 & 13.8 & 0.042 & 1.9 & 0.012 & 0.7 & 0.002 & 0.1 \\
\hline agforfish & 0.049 & 5.6 & -0.005 & -0.3 & 0.081 & 1.2 & -0.035 & -4.5 \\
\hline const & 0.106 & 22.9 & 0.079 & 3.5 & 0.197 & 7.0 & 0.027 & 2.3 \\
\hline manuf & -0.002 & -0.6 & 0.000 & 0.0 & -0.012 & -0.8 & -0.034 & -4.2 \\
\hline transp & -0.014 & -7.0 & 0.002 & 0.3 & 0.018 & 1.6 & -0.015 & -2.0 \\
\hline wholesale & 0.014 & 2.2 & 0.009 & 0.3 & -0.006 & -0.2 & 0.018 & 0.4 \\
\hline retail & 0.004 & 1.6 & -0.008 & -0.8 & 0.030 & 2.0 & -0.006 & -0.7 \\
\hline FIRE & 0.082 & 19.9 & 0.041 & 2.3 & 0.088 & 3.7 & 0.026 & 1.2 \\
\hline busserv & 0.042 & 8.2 & 0.006 & 0.3 & 0.059 & 1.9 & -0.017 & -0.8 \\
\hline persserv & 0.291 & 35.0 & 0.316 & 6.8 & 0.255 & 6.4 & 0.289 & 5.8 \\
\hline entmnt & 0.249 & 27.5 & 0.238 & 4.9 & 0.359 & 7.9 & 0.130 & 2.3 \\
\hline gardland & 0.247 & 15.8 & 0.118 & 2.3 & 0.265 & 1.9 & 0.035 & 1.9 \\
\hline repair & 0.047 & 11.9 & 0.018 & 1.2 & 0.091 & 3.8 & 0.041 & 3.2 \\
\hline other & -0.023 & -7.3 & -0.004 & -0.3 & 0.025 & 0.9 & -0.015 & -0.9 \\
\hline idaho & 0.019 & 8.8 & 0.025 & 2.4 & 0.002 & 0.2 & 0.006 & 0.7 \\
\hline oregon & 0.011 & 7.6 & 0.014 & 2.0 & 0.004 & 0.6 & 0.010 & 1.6 \\
\hline mpop & -0.016 & -9.4 & -0.003 & -0.4 & -0.007 & -0.8 & -0.006 & -1.0 \\
\hline yrsinus & & & & & 0.0011 & 4.3 & 0.0010 & 3.2 \\
\hline engspkw & & & & & 0.022 & 3.3 & 0.016 & 2.9 \\
\hline Obs. & 169,677 & & 6,409 & & 6,153 & & 8,363 & \\
\hline PR2 & 0.076 & & 0.129 & & 0.090 & & 0.134 & \\
\hline
\end{tabular}

Source: 2005-2007American Community Survey.

\subsection{Probability of Being an Entrepreneur}

The marginal effects and $\mathrm{Z}$ statistics of the logit models on the probability of being an entrepreneur are shown in Table 3 and sample means of variables in the logit models are in Table 4. Regardless of ethnicity, age and age squared have a positive and negative effect, respectively, as expected in the quadratic formulation of the model. The highest probability of being an entrepreneur among the U.S. born occurs at 51.3 years of age for White non-Latinos and 52.5 years of age for Latinos. The peak probability of being an entrepreneur occurs earlier among immigrants, 45.7 years of age for Latinos and to 47.5 years of age for White non-Latinos. 
Table 4. Sample means of variables included in the logit models by ethnicity and nativity in the Pacific Northwest, 2005-2007

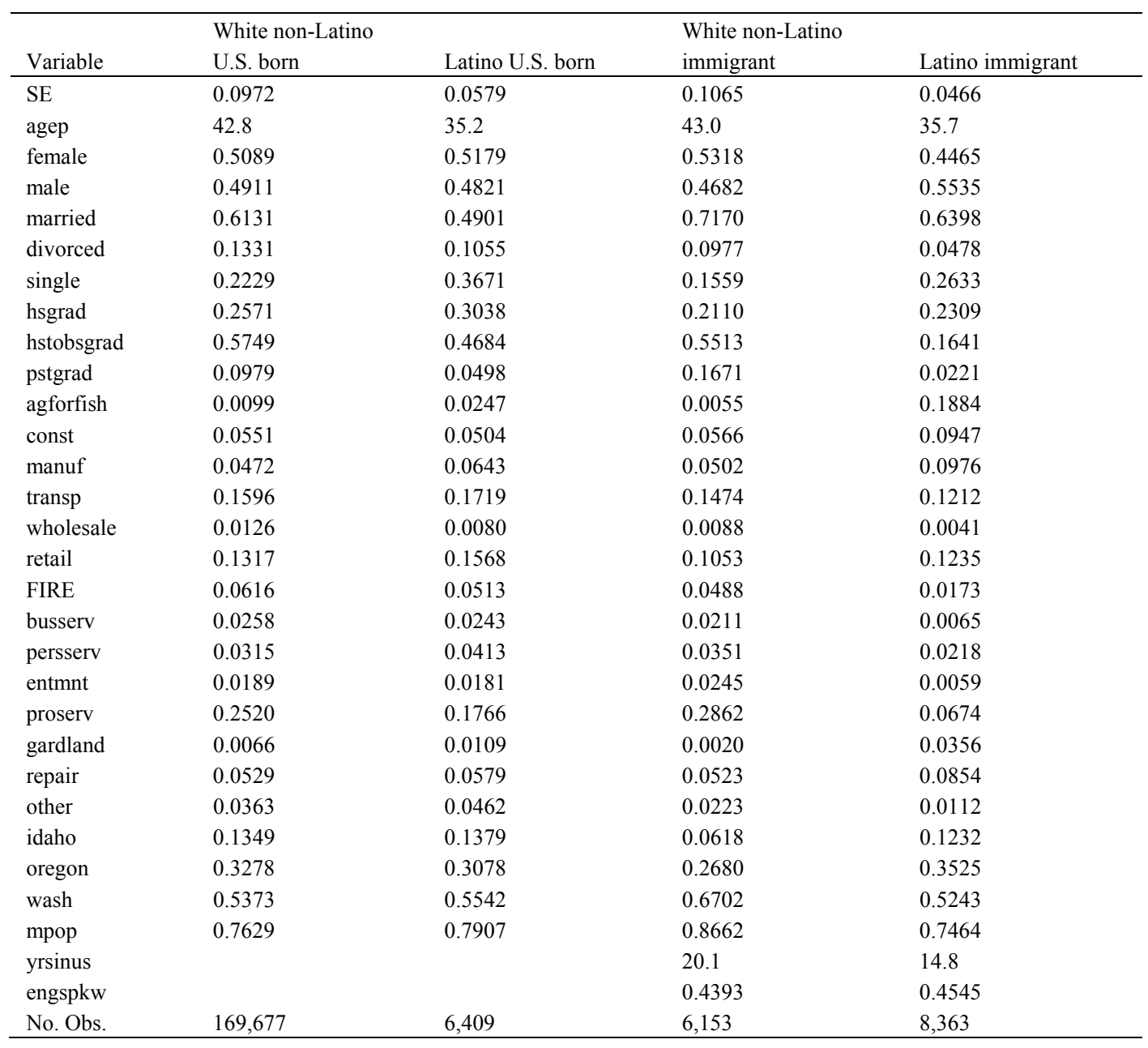

Source: 2005-2007 American Community Survey.

See Table 2 for names and description of variables.

Regardless of ethnicity, females are less likely to be self-employed than their male counterparts (1.4\% to $2.0 \%)$ but the gap is larger among White non-Latinos than Latinos.

Married White non-Latinos and Latinos are, respectively, $1.4 \%$ and $1.9 \%$ more likely to be entrepreneurs than their widowed/separated counterparts. White non-Latino divorcees are $0.9 \%$ more likely to be entrepreneurs than their widowed/separated counterparts.

Latino immigrants with a high school degree are $0.9 \%$ less likely to be entrepreneurs than their counterparts without a high school degree. The U.S. born individuals with a college education are $2 \%$ more likely to be entrepreneurs than their peers without a high school degree. The effect of postgraduate education on the probability of being self-employed, relative to individuals without a high school degree, is twice as large among the White non-Latinos compared to Latinos, $8.4 \%$ and $4.2 \%$, respectively. Among the Latino immigrants, those with a high school degree are $0.9 \%$ less likely to be self-employed relative to their peers without a high school degree $(\mathrm{p}<0.10)$.

White non-Latinos born in the United States are less likely to be entrepreneurs in transportation and other occupations relative to their peers in professional services (1.4\% and $2.3 \%$, respectively). However, they are more likely to be entrepreneurs in repair, business services, agriculture, fish, and forestry, FIRE, construction, gardening and landscaping, entertainment, and personal services relative to their peers in professional services (ranging from $4.7 \%$ in repair to $29.1 \%$ in personal services). Latinos born in the United States are more likely to be entrepreneurs in construction, gardening and landscaping, entertainment, and personal services than their peers in professional services (ranging from $7.9 \%$ in construction to $31.6 \%$ in personal services). 
White non-Latino immigrants are more likely to be entrepreneurs in FIRE, construction, gardening and landscaping, entertainment, and personal services relative to their peers in professional services (ranging from $9.1 \%$ in repair to $35.9 \%$ in entertainment). Among the Latino immigrants, agriculture, fish, and forestry, construction, manufacturing, and transportation are occupations in which they are less likely to be entrepreneurs compared to their peers in professional services (ranging from $1.5 \%$ in transportation to $3.5 \%$ in agriculture, fish, and forestry). In contrast, Latino immigrants are more likely to be entrepreneurs in repair, gardening and landscaping, entertainment, and personal services than their peers in professional services (ranging from $3.5 \%$ in gardening and landscaping to $28.9 \%$ in personal services). The marginal effects among the U.S. born Latinos are slightly higher than those among Latino immigrants.

The fixed effect of state is only significant among the U.S. born. Latinos in Idaho and Oregon, respectively, are $2.5 \%$ and $1.4 \%$ more likely to be entrepreneurs relative to Latinos residing in Washington. This effect is less pronounced among the White non-Latinos; they are more likely to be self-employed in Idaho (1.9\%) or Oregon $(1.1 \%)$ than in Washington. The proportion of metropolitan population has a significant negative effect on the probability of being an entrepreneur only among the White non-Latinos $(0.16 \%$ for a $10 \%$ increase in the proportion of metropolitan population). Henderson, Low, \& Weiler (2007) find that the number of entrepreneurs is higher in less populated, more insular counties. However, Fairlie \& Robb (2009) find that urban environments favor the likelihood of having profits above $\$ 10,000$ or being employer firms.

Table 5. Non-linear decomposition of the probability of being self-employed: Latinos vs. White non-Latinos in the Pacific Northwest, 2005-2007

\begin{tabular}{lll}
\hline & U.S. born & Immigrant \\
\hline Difference & 0.0394 & 0.0598 \\
Explained difference & \multicolumn{2}{c}{$\%$} \\
Age & $29.16^{* *}$ & 0.08 \\
Gender & 1.79 & $-2.46^{* *}$ \\
Marital status & 3.44 & 3.61 \\
Educational attainment & $12.23^{* *}$ & -1.65 \\
Occupation & -2.86 & $12.41^{* *}$ \\
State & 1.14 & -2.96 \\
Metropolitan population & 0.37 & -1.00 \\
Years in the U.S. & & $16.03^{* *}$ \\
Good command of English & & $-1.58^{* *}$ \\
Total explained & 45.25 & 22.47 \\
\hline
\end{tabular}

Source: 2005-2007 American Community Survey.

Note: ${ }^{* *} \mathrm{p}<0.01$. Age: agep and agepsq. Gender: female. Marital status: married, divorced, and single. Educational attainment: hsgrad, hstobsgrad, and pstgrad. Occupation: agforfsh, cnstr, manf, transcom, wholesale, retail, FIRE, busserv, persserv, entrec, gardland, repair, and other. State: idaho, oregon, and wash. Metropolitan population: mpop. Years in the U.S.: yrsinus. Good command of English: engspkw.

The number of years in the United States is also significant for Latino immigrants: $0.1 \%$ for each year since their arrival; $2.0 \%$ for the average Latino; and $1.5 \%$ for the average White non-Latino. A good command of the English language increases the likelihood of being an entrepreneur by $2.2 \%$ among White non-Latinos and by $1.6 \%$ among Latinos. We examine sets of variables that affect the probability of being an entrepreneur based on observable group endowments using non-linear decomposition (Table 5). Immigrants have a larger difference compared to the U.S. born ( 0.0598 and 0.0394 , respectively). There are nine sets of variables aggregated into age, gender, marital status, educational attainment, occupation, state, metropolitan population, and in the case of immigrants, years in the United States, and good command of the English language. Out of the predicted difference between the U.S. born ethnic groups, $45.3 \%$ is explained by differences in observable attributes. Unexplained differences are often attributed to discrimination but they also mix the effect of having an incomplete model specification. We do not elaborate in the unexplained differences because of the difficulty in interpreting results (see Fairlie \& Robb, 2009). Age explains $29.2 \%$ of the difference in the probability of being an entrepreneur and educational attainment explains $12.2 \%$. Marital status and gender explain $5.2 \%$ of the difference. State and the proportion of metropolitan population explain $1.5 \%$ of the difference. Occupations explain a negative $2.9 \%$ difference, suggesting that Latinos have favorable occupational distributions for the probability of being entrepreneurs. Decomposition estimates can be negative or positive: negative estimates 
indicate that the variable(s) in question contribute(s) to the inequality in the direction that runs counter to the overall inequality (Stewart-Williams, 2009, p. 1074).

The non-linear decomposition only explains $22.5 \%$ of the difference between the immigrants of different ethnicity. Years in the United States, occupation, and marital status explain $16.0 \%, 12.4 \%$, and $3.6 \%$ of the difference, respectively. State and proportion of metropolitan population had a negative $4 \%$ of explained difference. Gender and good command of the English language contribute with a negative 4\% explained difference.

While educational attainment is significant to explain the difference between White non-Latinos and Latinos being entrepreneurs among the U.S. born individuals, this does not hold for immigrants. Moreover, type of occupation is significant to explain differences between White non-Latinos and Latinos being entrepreneurs among the immigrants but this does not hold among the U.S. born individuals (Note 3). This is in agreement with authors stating that educational characteristics acquired by immigrants prior to their arrival in the United States are not transferable or equivalent to U.S. education (Fairlie \& Woodroff, 2007; Toussaint-Comeau, Smith, \& Comeau, 2005). The interplay of socio-economic and demographic variables contributes to modify the probability of being an entrepreneur. Some variables are changed by the individuals in their lifetime. Lofstrom \& Bates (2013) find that education positively predicts self-employment entry in fields requiring high skill levels and negatively predicts self-employment entry in fields requiring low skill levels. We find that the type of occupation significantly changes the probabilities of being an entrepreneur relative to those working in professional services, or any other occupation used as a reference group. The correlations between the levels of educational attainment and occupations in the ACS data help explain the interplay of these variables in self-employment income. Among the U.S. born, White non-Latinos have 36 significant correlations and Latinos only five. Among the immigrants, White non-Latinos have 16 significant correlations and Latinos only seven. Thus, education is more correlated with occupations among the U.S. born than it is among immigrants (Note 4). This is not surprising given that $18 \%$ of U.S. born Latinos and $58 \%$ of Latino immigrants do not have a high school degree in the PNW. In contrast, only $7 \%$ of the immigrants and U.S. born White non-Latinos do not have a high school degree.

\subsection{Self-Employment Income}

In order to quantify the factors that determine SEI, its natural logarithm is regressed with respect to the same variables in the logit model by ethnicity and nativity. The estimated coefficients for the predictors of the $\operatorname{lnSEI}$ in equation (2) are in Table 6 and sample means of variables in the semi-log models are in Table 7. First we discuss the continuous variables followed by the dummy variables. Age and age squared are significant for both White non-Latinos and Latinos born in the United States. Peak earnings occur at 50.0 years of age for U.S. born and for White non-Latino immigrants, and 52.5 years of age for Latino immigrants. The proportion of metropolitan population is only significant for immigrant Latinos and SEI diminishes by $4.1 \%$ for every $10 \%$ increase in the proportion of metropolitan population. Fairlie \& Robb $(2009$, p. 383) find that the dummy variable for urbanicity, controlling for race and ethnicity, has a positive $18.3 \%$ effect on sales (SEI in our case) using data from the Characteristics of Business Owners. This sharp difference in the marginal effect of our continuous variable, proportion of metropolitan population in clusters of at least 100,000 people, and the urbanicity variable (discrete) used by Fairlie \& Robb needs to be further investigated. The number of years in the United States is statistically insignificant for immigrants' SEI.

To examine the effects of dummy variables in SEI, we estimate the percentage change in SEI with respect to changes in the dummy variables from 0 to 1 following Kennedy (1981) (Table 8). Latinas have the largest and smallest gender gap, 63\% for the immigrants and 43\% for the U.S. born (Note 5). White non-Latinas U.S. born earn $53.9 \%$ less than their male counterparts and immigrant White non-Latinas earn $47.5 \%$ less than their male counterparts. Discussion of the gender gap in SEI by ethnicity and nativity is beyond the scope of this paper; Fairlie \& Robb (2009) discuss gender issues and business performance and Lofstrom \& Bates (2009) address wage and self-employment income by ethnicity and nativity. Married and divorced White non-Latinos born in the United States have higher earnings (34.1\% and 23.5\%, respectively) than their widowed/separated counterparts.

Educational attainment is not significant in determining self-employment income for any of the groups considered. Figure 1a depicts that for both U.S. born and immigrant White non-Latinos SEI increases with educational attainment with a notorious increase for individuals with a postgraduate degree. In contrast, Latinos show a negative payoff for a high school degree or for some college education or college degree. However, similar to White non-Latinos, Latinos also show a notorious increase for individuals with a postgraduate degree. 
Lofstrom \& Bates $(2009$, p. 433) show that female SEI increases with educational attainment for both Latinos and White non-Latinos using panel data from the 1996 and 2001 from the Survey of Income Program Participation. Figure $1 \mathrm{~b}$ depicts differences in the structure of each population with respect to school attainment. U.S. born Latinos have a considerable lower number of individuals with postgraduate studies compared to White non-Latinos. More than one-half of Latino immigrants do not have a high school degree and less than five percent of them have postgraduate studies. In this sense, Latino immigrants in the PNW have a skewed population distribution toward the low-skilled as opposed to a bimodal distribution referred by Robles \& Cordero-Guzmán (2007).

All percentage effects in the different occupations are relative to self-employed individuals working in professional services. With a few exceptions, most of the individuals in different occupations earn less than individuals in professional services. White non-Latinos U.S. born self-employed in manufacturing, transportation, retail, entertainment, gardening and landscaping, repair, and other occupations earn between $29.5 \%$ and $57.6 \%$ less than their peers in professional services. Only those individuals self-employed in FIRE and business services, respectively, earn $65.0 \%$ and $26.5 \%$ more than their peers in professional services. Among the U.S. born Latinos, those self-employed in FIRE earn 109.8\% more than their peers in professional services, but those self-employed in other services earn $85.3 \%$ less than those in professional services. White non-Latino immigrants self-employed in manufacturing and wholesale earn $62.9 \%$ and $96.5 \%$ less than those in professional services. However, White non-Latino immigrants self-employed in business services earn $136.6 \%$ more than their peers in professional services.

Table 6. OLS of log self-employment income (\$) by ethnicity and nativity in the Pacific Northwest, 2005-2007

\begin{tabular}{|c|c|c|c|c|c|c|c|c|}
\hline \multirow{3}{*}{$\begin{array}{l}\text { Variable } \\
\text { agep }\end{array}$} & \multirow{2}{*}{$\begin{array}{l}\text { White non-Latino } \\
\text { U.S. born } \\
\text { Coeff. }\end{array}$} & \multirow{3}{*}{$\begin{array}{l}\text { Std. Err. } \\
0.010\end{array}$} & \multicolumn{2}{|c|}{ Latino U.S. born } & \multicolumn{2}{|c|}{$\begin{array}{l}\text { White non-Latino } \\
\text { immigrant }\end{array}$} & \multicolumn{2}{|c|}{ Latino immigrant } \\
\hline & & & Coeff. & Std. Err. & Coeff. & Std. Err. & Coeff. & Std. Err \\
\hline & $0.136 * * *$ & & $0.127 *$ & 0.069 & 0.0863 & 0.049 & 0.100 & 0.061 \\
\hline agepsq & $-0.00136 * * *$ & 0.0001 & -0.00127 & 0.0007 & -0.00103 & 0.0006 & -0.00095 & 0.0007 \\
\hline female & $-0.775 * * *$ & 0.030 & $-.533 * *$ & 0.200 & $-.633 * * *$ & 0.150 & $-.976 * * *$ & 0.205 \\
\hline married & $0.297 * * *$ & 0.083 & -0.150 & 0.548 & 0.427 & 0.455 & 0.385 & 0.353 \\
\hline single & -0.00433 & 0.091 & -0.357 & 0.581 & 0.276 & 0.523 & 0.249 & 0.401 \\
\hline hsgrad & 0.0844 & 0.066 & -0.106 & 0.323 & 0.0587 & 0.291 & -0.0211 & 0.208 \\
\hline hstobsgrad & -0.0962 & 0.062 & -0.492 & 0.298 & -0.203 & 0.275 & -0.176 & 0.212 \\
\hline pstgrad & 0.0563 & 0.072 & 0.001 & 0.445 & 0.252 & 0.322 & -0.763 & 0.464 \\
\hline agforfish & -0.0561 & 0.126 & 0.691 & 0.878 & 0.0300 & 0.783 & $-1.80 * * *$ & 0.457 \\
\hline const & 0.0348 & 0.052 & 0.250 & 0.375 & 0.388 & 0.254 & -0.0110 & 0.289 \\
\hline transp & $-0.521 * * *$ & 0.052 & -0.138 & 0.334 & -0.0204 & 0.246 & -0.104 & 0.329 \\
\hline wholesale & 0.105 & 0.123 & 1.553 & 0.999 & $-2.97 * * *$ & 0.863 & $2.178^{*}$ & 1.103 \\
\hline retail & $-0.348 * * *$ & 0.054 & -0.449 & 0.398 & -0.0600 & 0.277 & -0.217 & 0.327 \\
\hline FIRE & $0.502 * * *$ & 0.052 & $0.820 *$ & 0.397 & 0.413 & 0.292 & 0.503 & 0.512 \\
\hline busserv & $0.238 * *$ & 0.079 & -0.0353 & 0.628 & $0.956^{*}$ & 0.435 & 0.0373 & 1.103 \\
\hline persserv & 0.0142 & 0.055 & -0.188 & 0.314 & 0.378 & 0.286 & 0.0855 & 0.318 \\
\hline entmnt & $-0.333 * * *$ & 0.061 & 0.0825 & 0.362 & -0.406 & 0.262 & -0.674 & 0.547 \\
\hline gardland & $-0.853 * * *$ & 0.105 & $-1.358 *$ & 0.604 & 0.955 & 0.867 & $-1.237 * *$ & 0.374 \\
\hline repair & $-0.495 * * *$ & 0.060 & -0.152 & 0.434 & -0.330 & 0.299 & -0.402 & 0.284 \\
\hline other & $-0.877 * * *$ & 0.094 & $-1.764 * *$ & 0.548 & 0.0189 & 0.499 & -0.605 & 0.813 \\
\hline idaho & $-0.141 * * *$ & 0.040 & -0.059 & 0.268 & -0.172 & 0.295 & -0.038 & 0.252 \\
\hline oregon & -0.006 & 0.030 & -0.069 & 0.202 & -0.155 & 0.155 & 0.0197 & 0.168 \\
\hline mpop & 0.0639 & 0.036 & 0.00190 & 0.252 & -0.0269 & 0.221 & $-0.410^{*}$ & 0.204 \\
\hline yrsinus & & & & & 0.009 & 0.0055 & 0.011 & 0.0091 \\
\hline constant & $6.268 * * *$ & 0.23 & $6.971 * * *$ & 1.33 & $7.521 * * *$ & 1.196 & $7.060 * * *$ & 1.268 \\
\hline No. Obs. & 16,360 & & 365 & & 653 & & 390 & \\
\hline $\mathrm{R} 2$ & 0.111 & & 0.158 & & 0.123 & & 0.233 & \\
\hline
\end{tabular}

$* \mathrm{p}<0.05, * * \mathrm{p}<0.01, * * * \mathrm{p}<0.001$

Source: 2005-2007 American Community Survey. 
Among Latino immigrants, those self-employed in agriculture, forestry or fisheries, gardening and landscaping, and manufacturing earn between $72.9 \%$ and $85.1 \%$ less than their peers in professional services. Those self-employed in wholesale earn almost four times more than their peers self-employed in professional services.

Table 7. Sample means of variables in the self-employment income regressions by ethnicity and nativity in the Pacific Northwest, 2005-2007

\begin{tabular}{|c|c|c|c|c|}
\hline & White non-Latino & & White non- & \\
\hline Variable & U.S. born & Latino U.S. born & immigrant & Latino immigrant \\
\hline $\operatorname{lnSEI}$ & 9.2544 & 9.0389 & 9.5388 & 9.1861 \\
\hline SEI & 31,221 & 23,171 & 36,351 & 24,187 \\
\hline agep & 46.3 & 41.4 & 45.5 & 39.1 \\
\hline female & 0.4307 & 0.4575 & 0.4472 & 0.4103 \\
\hline male & 0.5693 & 0.5425 & 0.5528 & 0.5897 \\
\hline married & 0.6894 & 0.6356 & 0.7703 & 0.7128 \\
\hline divorced & 0.1411 & 0.1260 & 0.1332 & 0.0795 \\
\hline single & 0.1426 & 0.2082 & 0.0735 & 0.1538 \\
\hline hsgrad & 0.2135 & 0.2192 & 0.2098 & 0.2077 \\
\hline hstobsgrad & 0.5906 & 0.5781 & 0.5421 & 0.2103 \\
\hline pstgrad & 0.1440 & 0.0740 & 0.1746 & 0.0359 \\
\hline agforfish & 0.0119 & 0.0110 & 0.0077 & 0.0359 \\
\hline const & 0.0983 & 0.0932 & 0.1302 & 0.1538 \\
\hline manuf & 0.0350 & 0.0438 & 0.0276 & 0.0256 \\
\hline transp & 0.0912 & 0.1123 & 0.1133 & 0.0846 \\
\hline wholesale & 0.0123 & 0.0082 & 0.0061 & 0.0051 \\
\hline retail & 0.0820 & 0.0658 & 0.0812 & 0.0897 \\
\hline FIRE & 0.0914 & 0.0685 & 0.0658 & 0.0282 \\
\hline busserv & 0.0320 & 0.0219 & 0.0260 & 0.0051 \\
\hline persserv & 0.0870 & 0.1699 & 0.0827 & 0.1410 \\
\hline entmnt & 0.0595 & 0.0877 & 0.0888 & 0.0231 \\
\hline proserv & 0.2960 & 0.2082 & 0.2741 & 0.1692 \\
\hline gardland & 0.0174 & 0.0247 & 0.0061 & 0.0590 \\
\hline repair & 0.0644 & 0.0548 & 0.0704 & 0.1692 \\
\hline other & 0.0217 & 0.0301 & 0.0199 & 0.0103 \\
\hline idaho & 0.1509 & 0.1616 & 0.0582 & 0.1231 \\
\hline oregon & 0.3537 & 0.3534 & 0.2864 & 0.3769 \\
\hline wash & 0.4954 & 0.4849 & 0.6554 & 0.5000 \\
\hline mpop & 0.7306 & 0.7879 & 0.8560 & 0.7527 \\
\hline yrsinus & & & 23.2 & 18.9 \\
\hline engspkw & & & 0.4717 & 0.5923 \\
\hline No. Obs. & 16,360 & 365 & 653 & 390 \\
\hline
\end{tabular}

Source: 2005-2007 American Community Survey.

See Table 2 for names and description of variables.

Good command of the English language is significant for immigrant Latinos, who earn $43.1 \%$ more than their counterparts with an English language deficiency. The effect of this dummy variable is $28.6 \%$ among the White non-Latino but it is statistically insignificant. 
Table 8. Effects of the dummy variables (percentage) on self-employment income by ethnicity and nativity in the Pacific Northwest, 2005-2007

\begin{tabular}{|c|c|c|c|c|}
\hline & $\begin{array}{l}\text { White non-Latino } \\
\text { U.S. born }\end{array}$ & Latino U.S. born & $\begin{array}{l}\text { White non-Latino } \\
\text { immigrant }\end{array}$ & $\begin{array}{l}\text { Latino foreign } \\
\text { immigrant }\end{array}$ \\
\hline female & -53.9 & -42.5 & -47.5 & -63.1 \\
\hline married & 34.1 & -25.9 & 38.2 & 38.1 \\
\hline divorced & 23.5 & -23.5 & 18.7 & 44.7 \\
\hline single & -0.8 & -40.9 & 14.9 & 18.4 \\
\hline hsgrad & 8.6 & -14.6 & 1.6 & -4.2 \\
\hline hstobsgrad & -9.3 & -41.5 & -21.4 & -18.0 \\
\hline pstgrad & 5.5 & -9.3 & 22.2 & -58.1 \\
\hline agforfish & -6.2 & 35.7 & -24.2 & -85.1 \\
\hline const & 3.4 & 19.7 & 42.7 & -5.1 \\
\hline manuf & -49.7 & 11.3 & -62.9 & -72.9 \\
\hline transp & -40.7 & -17.6 & -4.9 & -14.6 \\
\hline wholesale & 10.2 & 186.9 & -96.5 & 380.5 \\
\hline retail & -29.5 & -41.0 & -9.4 & -23.7 \\
\hline FIRE & 65.0 & 109.8 & 44.8 & 45.1 \\
\hline busserv & 26.5 & -20.7 & 136.6 & -43.5 \\
\hline persserv & 1.3 & -21.1 & 40.1 & 3.6 \\
\hline entmnt & -28.5 & 1.7 & -35.6 & -56.1 \\
\hline gardland & -57.6 & -78.6 & 78.5 & -72.9 \\
\hline repair & -39.2 & -21.8 & -31.3 & -35.7 \\
\hline other & -58.6 & -85.3 & -10.0 & -60.8 \\
\hline idaho & -13.2 & -9.1 & -19.4 & -6.7 \\
\hline oregon & -0.6 & -8.6 & -15.4 & 0.6 \\
\hline engspkw & & & 28.6 & 43.1 \\
\hline
\end{tabular}

Source: Table 6 .

After Kennedy (1981): (exp (B - (.5*Std. Err.^2)) -1$) * 100$.

Effects in shaded cells have significant coefficients $(\mathrm{p}<0.05)$ in Table 6.

Latinos working in gardening and landscaping and agriculture, fishery, and forestry are generally males and Latinas tend to dominate in personal services (ACS, 2008). These occupations require low to medium educational attainment with low to medium entry barriers as noted by Lofstrom \& Wang (2007).

The Oaxaca linear decomposition of the semi-log models for self-employment income in Table 9 quantifies the contributions of variables or sets of variables to explain SEI differences between White non-Latinos and Latinos. Latinos have lower earnings compared to White non-Latinos, $22.6 \%$ for the U.S. born and $34.6 \%$ for immigrants The differences in SEI among the U.S. born are almost entirely explained by the differences in endowments $(90.7 \%)$. Age and marital status contribute to explain $60 \%$ of the difference between Latinos and White non-Latinos. While the contribution of educational attainment is negligible to explain the difference in earnings between White non-Latinos and Latinos, type of occupation contributes $20 \%$ to explain the difference. The larger difference in earnings among the immigrants $(34.6 \%)$ is not explained by the variables included in the linear decomposition. Age, marital status, occupation, state, and years in the United States, explain 54.5\% of the difference but the proportion of metropolitan population, gender, educational attainment, and good command of English explained a negative $54.7 \%$. The occupational group is significant to explain ethnic differences among the U.S. born and immigrants, $19.9 \%$ and $26.1 \%$, respectively. Educational attainment for immigrants has a negative $28 \%$, which implies that if the earnings of White non-Latinos were estimated with the observed characteristics of Latinos, their earnings would be higher and the difference in SEI smaller. Linear decomposition of SEI without controlling for the occupational groups reveals that educational attainment explains 3.8\% (-11.9\%) of the predicted difference between White non-Latinos and Latinos among the U.S. born (immigrants) (results not shown in Table 9 but available from the authors upon request). However, the difference explained by educational attainment in both decompositions is statistically insignificant. 

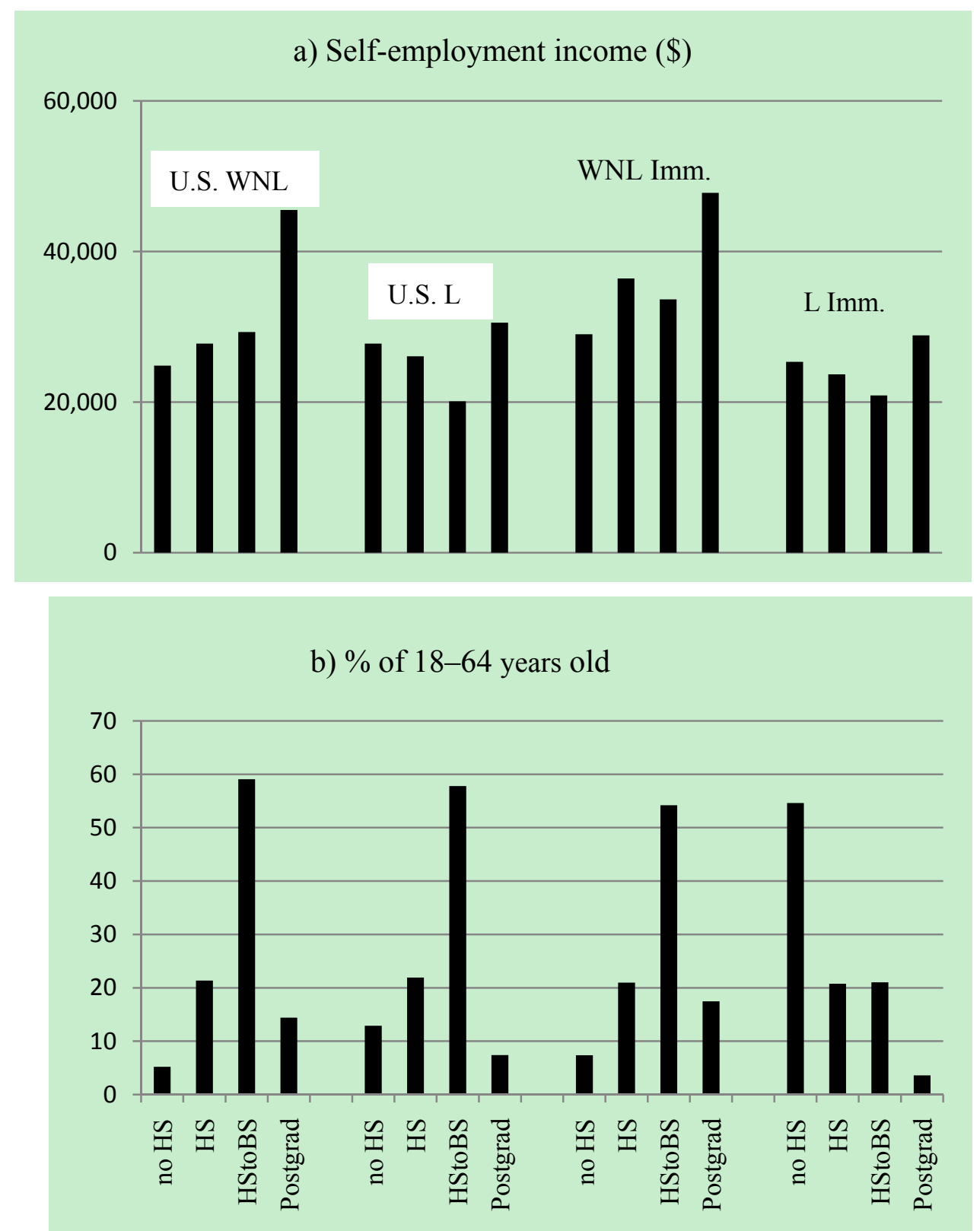

Figure 1a. Self-employment income of White non-Latinos and Latinos by nativity and school attainment (horizontal axis)

Figure 1b. Percentage of individuals between 18 and 64 years of age with respect to school attainment

Code: U.S. White non-Latino (U.S. WNL), U.S. Latino (U.S. L), White non-Latino immigrant (WNL Imm.), and Latino immigrant (L Imm.). Source: ACS 2005-2007.

The identification of factors that affect the probability of being self-employed between White non-Latinos and Latinos is clearer than the identification of factors affecting self-employment earnings between the two groups. Age and education among the U.S. born, and gender, occupation, years in the United States, and good command of the English language among the immigrants explain differences in the probability of being self-employed in the non-linear decomposition. Age, gender, and occupation explain most of the difference in SEI among the U.S. born. In contrast to Fairlie \& Robb (2009) and Lofstrom \& Bates (2013), we find that educational attainment has a negligible contribution to explain differences in SEI among the U.S. born and a mixed effect among immigrants. 
Table 9. Linear decomposition of self-employment income: White non-Latinos vs. Latinos in the Pacific Northwest, 2005-2007

\begin{tabular}{|c|c|c|}
\hline & U.S. born & Immigrant \\
\hline Difference & $0.226^{*}$ & $0.346^{* *}$ \\
\hline Explained difference & Percentage & \\
\hline Age & $50.08 * *$ & 5.92 \\
\hline Gender: female & 11.76 & -7.77 \\
\hline Marital status & $9.67 * *$ & 6.95 \\
\hline Educational attainment & -0.04 & -28.07 \\
\hline Occupation & $19.91 *$ & $26.16^{*}$ \\
\hline State & 0.67 & 4.66 \\
\hline Metropolitan population & -1.39 & -6.52 \\
\hline Years in the U.S. & & $10.79 *$ \\
\hline Good command of English & & $-12.33 *$ \\
\hline Total explained & $90.65 * *$ & -0.21 \\
\hline Obs. White non-Latino & 16,330 & 653 \\
\hline Obs. Latino & 365 & 390 \\
\hline
\end{tabular}

\section{Summary and Conclusions}

In this paper, we examine the factors that determine the likelihood of choosing to be self-employed or an entrepreneur in the PNW and determine how these factors contribute to their income. The ACS data 2005-2007 reveals that $5.5 \%$ of Latinos are self-employed compared to 9.4\% among White non-Latinos. Younger and less educated Latinos have limited choices for entering into high-skilled occupations with high entry barriers linked to personal wealth. Decomposition of logit models to predict the probability of being self-employed show that age and educational attainment explain $41 \%$ of the differences between U.S. born Latinos and White non-Latinos In contrast, occupation and the number of years in the United States explain $28 \%$ of the difference in the probability of being an entrepreneur among immigrants. Being female and having a good command of the English language contribute to explain a negative $4 \%$ difference, which means that if the characteristics of Latinos were used to estimate the probability of being self-employed for White non-Latino immigrants, the gap would be $4 \%$ smaller.

As far as SEI is concerned, Latino immigrants have a $4.1 \%$ lower SEI for every $10 \%$ increase in the proportion of metropolitan population. White non-Latino females earn $47.5 \%$ to $53.9 \%$ less than their male counterparts. Latinas born in the United States earn $42.5 \%$ less than their male counterparts and immigrant Latinas earn $63.1 \%$ less than their male counterparts. All levels of school attainment are statistically insignificant. However, type of occupation has a significant effect on SEI. Individuals in lower skilled and low-level entry barrier occupations such as gardening and landscaping earn $57.6 \%$ to $72.9 \%$ less than individuals in professional services, depending on ethnicity and nativity. In contrast, individuals in high-skilled and high-level entry barrier occupations such as finance, insurance and real estate earn $65.0 \%$ to $109.8 \%$ more than individuals in professional services, depending on ethnicity. Linear decomposition results indicate that the differences in SEI between U.S. born Latinos and White non-Latinos are almost fully explained by age, marital status, and type of occupation. In contrast, the linear decomposition results for immigrants are mixed, as the overall difference explained by the semi-log model is close to zero percent. Type of occupation, state, and years in the United States significantly explain $43 \%$ of the difference between the two ethnic groups, but gender, educational attainment, proportion of metropolitan population, and good command of the English language are non-significant to explain negative differences totaling $43 \%$.

Type of occupation significantly contributes to explain the ethnic gap in SEI for both U.S. born and immigrants, while education is statistically insignificant to explain differences in SEI. Why is education relevant to explain the difference in the probability of being SE between White non-Latinos and Latinos among the U.S. born, but it is not significant to explain ethnic differences in SEI? The choice to become an entrepreneur is related to the perceptions of opportunities that are linked to education among the U.S. born. However, SEI is linked to age, marital status, and the type of occupation chosen and not necessarily the skills acquired through traditional 
education. Age can bring experience or maturity, and married individuals have an incentive to be self-employed either by need or opportunity. The occupational group chosen, related to skills and entry barriers complement the factors determining SEI. The variables from the ACS and the observations for immigrants in the PNW, in contrast to the Characteristics of Business Owners Survey used by Fairlie \& Robb (2009) and the Survey of Income Program Participation used by Lofstrom \& Bates (2013),may not properly reflect the complexity of SEI, though this finding suggests further verification or expansion of the data set to include a larger mass of Latinos, e.g., California. The difference in the probability of being self-employed between White non-Latinos and Latinos, among immigrants, is explained by the number of years in the United States and the type of occupation.

Policies aimed to increase entrepreneurship and narrow the ethnic self-employment income gap should take into account the skewed distribution of skills and educational attainment of Latinos born in the United States and abroad. Emphasis on education as a vehicle for occupational choices and training to improve existing businesses and technical skills for self-employed U.S. born Latinos is recommended. Wide spectrum policies to enhance the performance of Hispanic-owned firms should promote entrepreneurial education in primary and secondary schooling, including mentorships with established businesses, as a complement to entrepreneurial education at higher levels and in the trenches of small and family-managed Latino businesses. However, in the case of Latino immigrants, given that educational attainment prior to their arrival to the United States is not fully transferable, mostly for the low-skilled, there is need to improve their skills within the occupational group or consider relocation to another group that is better suited for their skills and capital. The challenge is how to incentivize necessity-based Latino immigrant entrepreneurs to improve their skills at the same time they sustain themselves or their families. Opportunity-based Latino immigrants are likely to survive in the business world but they may benefit from mentoring and facilitating access to capital to expand their businesses.

\section{Acknowledgments}

Funding for this research project was provided, in part, by the Idaho Agricultural Experiment Station and the USDA-NIFA. The first author acknowledges fruitful interactions with colleagues of the North Central Education/Extension and Research Activity 216 "Latinos and Immigrants in Midwestern Communities." An earlier version of this paper was presented at the Western Economic Association International Conference, San Diego, CA June 2011. The authors appreciate the comments from the editor and anonymous reviewers.

\section{References}

Acs, Z. J., Desai, S., \& Hessels, J. (2008). Entrepreneurship, economic development and institutions. Small Business Economics, 31, 219-234. http://dx.doi.org/10.1007/s11187-008-9135-9

American Community Survey (ACS). (2008). Public Use Micro data Sample (PUMS) 2005-2007 3-Year. U.S. Census Bureau. Retrieved from http://factfinder.census.gov/home/en/acs_pums_2007_3yr.html

Blinder, A. S. (1973). Wage discrimination: reduced form and structural estimates. The Journal of Human Resources, 8, 436-455. http://dx.doi.org/10.2307/144855

Dávila, A., \& Mora, M. T. (2008). Changes in the relative earnings gap between natives and immigrants along the U.S.-Mexico border. Journal of Regional Science, 48, 525-45. http://dx.doi.org/10.1111/j.1467-9787.2008.00562.x

Fairlie, R. W. (2005). An extension of the Blinder-Oaxaca decomposition technique to logit and probit models. Journal of Economics and Social Measurement, 30, 305-316.

Fairlie, R. W., \& Robb, A. M. (2009). Gender differences in business performance: evidence from the characteristics of Business Owners Survey. Small Business Economics, 30, 375-395. http://dx.doi.org/10.1007/s11187-009-9207-5

Fairlie, R., \& Woodruff, C. (2007). Mexican entrepreneurship: a comparison of self-employment in Mexico and the United States. In G. Borjas (Ed.), Mexican Immigration to the United States (pp. 123-158). Chicago, The University of Chicago. http://dx.doi.org/10.7208/chicago/9780226066684.003.0005

Henderson, J., Low, S., \& Weiler, S. (2007). The drivers of regional entrepreneurships in rural and metro areas. In N. Walzer (Ed.), Entrepreneurship and Local Economic Development (pp. 81-102). Plymouth, UK: Lexington Books.

Hertz, T. (2010). Estimating the Metro Status of PUMAs. Edited by United States Department of Agriculture, Economic Research Service.

Kennedy, P. (1981). Estimation with correctly interpreted dummy variables in semilogarithmic equations. American Economic Review, 71, 801. 
Lofstrom, M., \& Bates, T. (2009). Latina entrepreneurship. Small Business Economics, 33, 427-439. http://dx.doi.org/10.1007/s11187-009-9203-9

Lofstrom, M., \& Bates, T. (2013). African Americans' pursuit of self-employment. Small Business Economics, 40, 73-86. Retrieved from http://www.springerlink.com/content/k310t18j11j564w7/fulltext.pdf

Lofstrom, M., \& Wang, C. (2007). Mexican-Hispanic self-employment entry: the role of business start-up constraints. Annals of the American Academy of Political and Social Science, 613, 32-46. http://dx.doi.org/10.1177/0002716207303577

Mora, M. T. (2006). Self-employed Mexican immigrants residing along the U.S.-Mexico border: the earnings effect of working in the U.S. versus Mexico. International Migration Review, 40, 885-98. http://dx.doi.org/10.1111/j.1747-7379.2006.00047.x

Oaxaca, R. (1973). Male-Female wage differentials in urban labor markets. International Economic Review, 14, 693-709. http://dx.doi.org/10.2307/2525981

Pew Hispanic Center. (2008a). Statistical Portrait of Hispanics in the United States, 2007. Retrieved from http://pewhispanic.org/files/factsheets/hispanics2007/Table-1.pdf

Pew Hispanic Center. (2008b). Characteristics of the Population by Race, Ethnicity and Nativity: 2007. Retrieved from http://pewhispanic.org/states/pdf/ID_07.pdf

Puryear, A. N., Rogoff, E. G., Lee, M., Heck, R. K. Z., Grossman, E. B., Haynes, G. W., \& Onochie, J. (2008). Sampling minority business owners and their families: the understudied entrepreneurial experience. Journal of Small Business Management, 46, 422-455. http://dx.doi.org/10.1111/j.1540-627X.2008.00251.x

Robles, B., \& Cordero-Guzmán, H. (2007). Latino self-employment and entrepreneurship in the United States: an overview of the literature and data sources. Annals, 613, 18-31. http://dx.doi.org/10.1177/0002716207303541

Rodríguez, A., \& Devadoss, S. (2014). Wage gap between White non-Latinos and Latinos by nativity and gender in the Pacific Northwest, U.S.A. Journal of Management and Sustainability, 4(1).

Stewart-Williams, J. A. (2009). Using non-linear decomposition to explain the discriminatory effects of male-female differentials in access to care: a cardiac rehabilitation case study. Social Science and Medicine, 69, 1072-1079.

Toussaint-Comeau, M., Smith, T., \& Comeau, L. Jr. (2005). Occupational attainment and mobility of Hispanics in a changing economy. A Report to the Pew Hispanic Center. Retrieved from http://pewhispanic.org/files/reports/59.1.pdf

Valdez, Z. (2009). Mexican American entrepreneurship in the Southwest. In J. S. Buttler, A. Morales, \& D. L. Torres (Eds.), An American Story: Mexican American Entrepreneurship and Wealth Creation (pp. 175-195). West Lafayette: Purdue University Press.

\section{Notes}

Note 1. Throughout this paper, we refer to White non-Latinos as an "ethnic" group, which is used as a base to compare with Latinos as another ethnic group. We also use self-employed and entrepreneur interchangeably.

Note 2. Binomial logit models have been used by economists to ascertain choices such as entering or not entering the labor market and semi-log models have been widely used in human capital theory of earnings determination (Lofstrom \& Wang, 2007; Fairlie \& Woodruff, 2007).

Note 3. The acquisition of some college or postgraduate education, for example, is significant for U.S. born individuals in the logit regression but this is not the case for immigrants (Table 2). Non-linear decomposition of the probability of SE not controlling for occupational groups reveals that educational attainment explains $10.9 \%$ $(5.5 \%)$ of the predicted difference between White non-Latinos and Latinos among the U.S. born (immigrants). However, the variation explained by educational attainment is only significant among the U.S. born.

Note 4. The signs of the correlations show that among the U.S. born Latinos with only a high school degree (postgraduate studies) are negatively (positively) correlated with business services. Among the Latino immigrants educational attainment is positively correlated with occupations such as FIRE, entertainment, professional services, business services, and others, but education is negatively correlated with agriculture. There 
are four positive correlations between occupational groups and individuals with postgraduate education and two positive correlations for individuals with some college education or a college degree.

Note 5. The coefficient for immigrant Latinas in Table 6 is -0.976 , it would be approximated as $97.6 \%$ less income than males (the base group); however, the correct change is $-63.1 \%\left(\left(\exp \left(-0.976-\left(0.5 * 0.205^{2}\right)\right)-1\right)\right.$ *100) lower than males when using Kennedy's method. The correction is seldom applied but it has been used by Mora (2005) and Dávila and Mora (2008). We discuss the results for the significant coefficients of the dummy variables in Table 6 following Kennedy's method.

\section{Copyrights}

Copyright for this article is retained by the author(s), with first publication rights granted to the journal.

This is an open-access article distributed under the terms and conditions of the Creative Commons Attribution license (http://creativecommons.org/licenses/by/3.0/). 